\title{
Early school-leaving in the Netherlands: The role of family resources, school composition and background characteristics in early school-leaving in lower secondary education
}

Citation for published version (APA):

Traag, T., \& van der Velden, R. K. W. (2011). Early school-leaving in the Netherlands: The role of family resources, school composition and background characteristics in early school-leaving in lower secondary education. Irish Educational Studies, 30(1), 45-62. https://doi.org/10.1080/03323315.2011.535975

Document status and date:

Published: 01/01/2011

DOI:

10.1080/03323315.2011.535975

Document Version:

Publisher's PDF, also known as Version of record

Document license:

Taverne

Please check the document version of this publication:

- A submitted manuscript is the version of the article upon submission and before peer-review. There can be important differences between the submitted version and the official published version of record. People interested in the research are advised to contact the author for the final version of the publication, or visit the DOI to the publisher's website.

- The final author version and the galley proof are versions of the publication after peer review.

- The final published version features the final layout of the paper including the volume, issue and page numbers.

Link to publication

\footnotetext{
General rights rights.

- You may freely distribute the URL identifying the publication in the public portal. please follow below link for the End User Agreement:

www.umlib.nl/taverne-license

Take down policy

If you believe that this document breaches copyright please contact us at:

repository@maastrichtuniversity.nl

providing details and we will investigate your claim.
}

Copyright and moral rights for the publications made accessible in the public portal are retained by the authors and/or other copyright owners and it is a condition of accessing publications that users recognise and abide by the legal requirements associated with these

- Users may download and print one copy of any publication from the public portal for the purpose of private study or research.

- You may not further distribute the material or use it for any profit-making activity or commercial gain

If the publication is distributed under the terms of Article 25fa of the Dutch Copyright Act, indicated by the "Taverne" license above, 


\title{
Early school-leaving in the Netherlands: the role of family resources, school composition and background characteristics in early school-leaving in lower secondary education
}

\author{
Tanja Traag ${ }^{\mathrm{a} *}$ and Rolf K. W. van der Velden ${ }^{\mathrm{b}}$ \\ ${ }^{a}$ Statistics Netherlands, The Netherlands; ${ }^{b}$ Research Centre for Education and the Labour \\ Market (ROA), Maastricht, The Netherlands
}

\begin{abstract}
This study explains early school-leaving in lower secondary education in the Netherlands, taking into account background characteristics, family resources and school composition factors at the same time. We distinguish four groups of school-leavers: 'dropouts' (those without any qualification), those who leave school with a diploma in lower secondary education ('low qualified'), those who complete apprentice-based tracks ('apprentices') and those who continue education and receive a full upper secondary qualification ('full qualification'). The breakdown into these four groups reveals clear differences in the effects of different factors on the risk of early school-leaving.
\end{abstract}

Keywords: early school-leaving; human capital theory; random coefficient model

\section{Introduction}

Early school-leaving has severe consequences for the life course of individual people, as well as a negative impact on society as a whole. It increases the risk of unemployment and low-paid jobs (Beckers and Traag 2005), and also correlates with higher levels of delinquency (Marie, Traag, and van der Velden 2009). At the same time, growing concerns about the future supply of sufficiently skilled workers resulted in the Lisbon goal of reducing the proportion of early school-leavers in all EU countries. For the Netherlands, the policy goal is to reduce the share of early schoolleavers to $8 \%$ in $2010 .{ }^{1}$ To combat early school-leaving, we need more insight into the underlying factors that cause pupils to leave school prematurely. Notwithstanding the extensive research in this area, there are still significant blind spots.

In this contribution, we shall improve current knowledge on early school-leaving in three ways. Firstly, we use a comprehensive model, taking into account family resources, school composition factors ${ }^{2}$ and background characteristics simultaneously. Secondly, we apply this model to longitudinal panel data that provide independent variables measured at age 12, well before early school-leaving takes place. And thirdly, instead of comparing just two groups - dropouts and those who stay in education - we differentiate more, by distinguishing subgroups of early school-leavers. This further distinction between students with a lower and those with a full upper secondary qualification is necessary because a lower secondary

\footnotetext{
*Corresponding author. Email: t.traag@cbs.nl
} 
qualification is no longer regarded as sufficient to enter the labour market (OECD 2007).

Dutch secondary education starts at age 12, when pupils have to choose between three different tracks (see Appendix 1 for an overview of the whole system). This contribution focuses on those pupils who started secondary education in the lowest track: pre-vocational secondary education (VMBO), which we shall refer to as lower secondary education. This lowest track accounts for about $55 \%$ of all enrolments at the start of secondary education. The other two tracks (senior general secondary education or HAVO, and pre-university education or VWO) are the academic tracks that specifically prepare for higher education. The reason for focusing on the lowest track of secondary education is that early school-leaving is rarely a problem in the two other tracks.

Our two research questions are:

(1) What family resources, school composition factors and background characteristics influence the risk of early school-leaving?

(2) Do the effects of family resources, school composition factors and background characteristics differ between the subgroups of early school-leavers?

Our results show that cognitive capacities and motivation are important factors in the prevention of early school-leaving, especially for boys. Surprisingly, we found no significant effects for having an ethnic minority background after controlling for parental resources. With respect to the differentiation between groups of schoolleavers, we found that the effects of all characteristics are always stronger for the dropout group than for the other two groups, suggesting that the underlying dimension is a continuum rather than a distinction between two or three totally different groups. Section 2 of this contribution elaborates the theoretical framework. In Section 3 we describe our data and the variables used in our analyses. Section 4 gives a description of the findings, and Section 5 contains the conclusions.

\section{Theoretical framework}

Human capital theory focuses mainly on individual decisions to invest in education, and is very useful for explaining mechanisms in early school-leaving. The decision to leave education can be regarded as a rational choice (Becker 1964; Boudon 1974), in which costs and benefits may be constrained by social-structural variables. An important mechanism is what Breen and Goldthorpe (1997) call 'relative risk aversion'; i.e. young people want to acquire a level of education that will allow them to attain a class position at least as good as that of their family of origin, so investments in education are constrained by social class (Shavit and Blossfeld 1993; O'Brien 2003). A lack of relevant family resources in this perspective is regarded as a lack of human capital (and as such, as a deficit).

In this contribution we do not intend to test the human capital approach as such, but we shall use it to make inferences on the processes underlying early schoolleaving. We will distinguish three groups of explanatory factors: ${ }^{3}$ family resources, school composition factors and background characteristics. 


\section{Family-related factors explaining early school-leaving}

Differences in school success not only relate to differences in individual characteristics, but also to differences in background. To understand how social origin leads to educational inequalities, we distinguish between different kinds of family resources (de Graaf and de Graaf 2002). These different resources determine the relative costs and benefits of staying in education. We distinguish the following four types of family resources: economic capital, human capital, social capital and cultural capital.

Let us look at the family's economic capital first. Parents with sufficient financial resources can provide their children with the material goods that they need in order to perform well at school; books and other learning materials, for example (de Graaf 1986; Coleman 1988). Parental income depends strongly on whether parents have paid work, and if so in what occupational group. Australian research has shown that school dropouts were more often from families where the father had a manual rather than a professional occupation, and where family income was low (Lamb 1994). In Ireland, $33 \%$ of children who come from families where the father is unemployed or low skilled did not continue school after the Junior Leaving Certification (National Youth Council of Ireland 2001).

A family's human capital is defined as the cognitively stimulating environment it provides, and is measured in terms of the parents' education level. Parents with higher education are more likely to have greater knowledge of the school system and to view higher education as the preferred option for their children (Lamb 1994; Rumberger 1983).

Cultural capital is an important factor in explaining intergenerational transmission of inequality (Bourdieu and Passeron 1977; DiMaggio 1982). Children of parents with high levels of cultural capital are able to adjust better to the dominant culture in schools than children of parents with less cultural capital. Children from the cultural elite are therefore more successful in school than children of culturally deprived parents, irrespective of their cognitive skills (de Graaf and de Graaf 2002).

Lastly, we consider the family's social capital. Among other things, this concerns the relationship between parents and children. An effective transmission of resources from parent to child requires sufficient interaction within the family (Coleman 1988). Children from single-parent families have less social interaction, as only one parent is available. This is also true for children in large families, where children need to share interaction time with other siblings. This means that children in single-parent families and children in large families benefit less from their parents' resources, increasing the probability of leaving school early (McLanahan and Sandefur 1994; Ní Bhrolcháin et al. 2000; US Department of Education 2001; Heard 2004). Based on the above we expect to find negative effects of economic, human, social and cultural capital on early school-leaving.

Ethnic background can be seen as a separate dimension in resources. Ethnic minorities may lack specific resources that are necessary to succeed in life. Most importantly, in the context of the Netherlands, they lack human capital since second generation migrants attain lower educational levels than natives in the Netherlands. In addition to that, pre-school participation rates are lower among second generation immigrants' children. Pre-school participation is especially important among these groups because it is at this young age that linguistic competences are 
developed (Geerdes, 2009). Speaking the language of the host country is an important ingredient for educational success.

\section{Effects of school composition}

Effects of school composition are of particular importance, as they are the principal mechanism for governments to combat the problem of early school-leaving (Audas and Willms 2001). Schools tend to differ strongly in terms of performance and early school-leaving. One major characteristic affecting performance and school careers is the proportion of children from ethnic minorities in a school. Studies in the Netherlands have revealed a clear relationship between a school's racial mix and the educational performance of its students (van der Werf, Lubbers, and Kuyper 2002; van der Slik, Driessen, and de Bot 2005). Two main mechanisms underlie this relationship. First, average language skills in schools with large proportions of ethnic minorities are lower, as many students come from immigrant families who have not lived in the country long. Secondly, in these schools students have access to fewer cultural resources from their peers as most of them are from a lower social background. Van der Werf, Lubbers, and Kuyper (2002) showed that students in urban areas are less successful than students in non-urban areas.

The Dutch education system (see Appendix 1) is highly stratified and consists of three different educational tracks. Some secondary schools offer only one or two tracks, others offer all three. An interesting school characteristic in this respect is whether students attend a school which also offers the upper academic tracks. Based on human capital theory, we would expect students in heterogeneous schools not only to learn from their teachers, but also from their co-students. In heterogeneous schools, weaker students can learn from and be stimulated by stronger ones, thus reducing their chances of leaving school early.

Summing up, we expect to find a positive effect for attending a school with a large share of ethnic minorities, as well as a positive effect for attending a school in an urban area. Also, we expect attending a heterogeneous school to have a negative effect on the risk of leaving school early.

\section{Background characteristics}

The most important individual factor in educational success is the students' cognitive abilities. Early school-leavers show lower levels of cognitive ability and perform less well in school compared to other students (Audas and Willms 2001; Alexander, Entwisle, and Kabbani 2001; Ensminger and Slusarcick 1992; Cairns, Cairns, and Neckerman 1989). In addition to differences in cognitive abilities, dropouts also do not work to their full potential (Barrington and Hendricks 1989) and show a lack of aspiration as well as motivation (Audas and Willms 2001; Alexander, Entwisle, and Horsey 1997). Recent studies on differential selection between boys and girls have shown that low-ability boys are selected out of university-bound programmes early on (Baucal, Pavlovic-Babic, and Willms 2006). In the Netherlands, relatively more boys than girls attend special education, boys perform less well in school, and significantly fewer boys than girls enter higher education (Marks and Fleming 1999; Rumberger 1995; Veendrick, Tavecchio, and Doornenbal 2004). ${ }^{4}$ It is not clear 
whether this lower performance by boys is caused by lower cognitive abilities or whether the effects of cognitive abilities are stronger for boys than for girls.

The second individual factor is participation and identification. Participating in school leads to identification (Beekhoven 2004; Voelkl 1995). If students identify with their school, participation is strengthened and students enjoy going to school. A lack of identification with the school results in a decrease in participation and an aversion to school, thus increasing the risk of early school-leaving (Audas and Willms 2001; Alexander, Entwisle, and Horsey 1997; Marks 1998).

Based on the previous findings described above, we expect to find positive effects of being a boy, negative effects for cognitive ability and motivational aspects, as well as negative effects for the degree to which students like their school. Also, we expect to find a significant interaction effect of gender and cognitive ability.

\section{Breakdown into subgroups of early school-leavers}

This contribution distinguishes subgroups of early school-leavers. The reason for this breakdown is that we expect that school-leavers with no diploma at all differ from school-leavers who did attain a diploma below the level of upper secondary education. We expect differences with respect to their characteristics, as well as to their opportunities in later life, as they have attained different levels of education. Therefore we anticipate that the effects will remain in the same direction, but be stronger for dropouts than for those who attained a qualification, albeit a low one. Our analyses assess whether our independent variables influence the risk of early school-leaving and compare these effects for each group of (early) school-leavers to the group of students that attained at least an upper secondary qualification.

\section{Data and methodology}

For this analysis we use a large representative longitudinal survey carried out in the Netherlands by Statistics Netherlands and academic researchers (Statistics Netherlands 1991; Driessen and van der Werf 1992). This survey, the so-called Secondary Education Student Cohort 1989 (VOCL'89) consists of 19,254 students from a random sample of 108 schools, who started secondary school in 1989/1990, and whose educational career has been followed since then. ${ }^{5}$ This makes it possible not only to determine the educational level at any given time, but also to see whether students repeated classes or dropped out, or whether they transferred to a higher or lower track of education. Furthermore, students were tested on school performance and non-verbal intelligence in the first year of secondary education. Parents of the students received a questionnaire at the start of the survey, with the aim of collecting information about the families and the pupils. Driessen and van der Werf (1992) tested the representativeness of the sample both at the level of the school ${ }^{6}$ and of the individual student. ${ }^{7}$ On the whole, the survey can be regarded as nationally representative for all students in the first year of secondary education in $1989 / 1990$. More specific information about the cohort study in general and missing data analyses can be found in the VOCL reports (Statistics Netherlands 1991; Driessen and van der Werf 1992). 


\section{Population}

All students who had ever attended lower secondary education (VMBO) were selected from the initial VOCL'89 population. Thus, even students who started secondary education in one of the two higher tracks (i.e. senior general secondary education HAVO or pre-university education VWO), but later moved down to the lower track were also included in our sample. This resulted in a total of approximately 10,000 students in lower secondary education (VMBO). These students were then divided into our subgroups of early school-leavers, based on their highest achieved level of education. The VOCL study covers only subsidised ${ }^{8}$ full-time education, so students who move to part-time education are no longer monitored. However, as one of the tracks in senior secondary vocational education (MBO) consists of apprenticeship training combined with school, and leads to a qualification at upper secondary level, we decided to form an extra subgroup of students of whom we know that left full-time education but entered one of these programmes. However, as we do not know whether they successfully completed this education, our dependent variable is divided into the following four groups:

- students with no diploma at all ('dropouts') $(N=1208)$;

- students with only a lower secondary education diploma (VMBO: 'low qualified') $(N=3409)$;

- students who successfully attained a diploma in lower secondary education and then moved to an apprenticeship training ('apprentices') $(N=1034)$; and

- students with a full upper secondary qualification (ISCED 3, 3b and 3c long or above, i.e. senior cycle of secondary level and higher in the Irish case) $(N=4828)$.

Table 1 presents an overview of all independent variables we use in our analysis (see Appendix 2 for a more detailed description of our variables).

\section{Statistical modelling}

Our analyses involve the breakdown of the total effect of individual, family and school characteristics on early school-leaving into two sources of variation: differences at the individual level and differences between schools. To deal with this, we use random coefficient or multilevel models. The basic idea of multilevel analysis is that data with a nested structure are not adequately represented by the probabilistic model of multiple regression analysis, but should be analysed in a hierarchical linear model or random coefficient model (Snijders and Bosker 1999; Goldstein 1995). We use a multinomial logistic model to take account of the fact that our dependent variable has four categories. Our model has a hierarchical structure in which individuals $i$ are nested in schools $j$. In this model $t$ denotes the reference category: students who attained a diploma in upper secondary education. For each of the remaining $t-1$ categories $s$, the two-level random intercept model specified is:

$$
\log \left(\frac{\pi_{i j}^{(s)}}{\pi_{i j}^{(t)}}\right)=\beta_{0}^{(s)}+\beta_{1}^{(s)} x_{i j}+u_{j}^{s}
$$


Table 1. Overview of variables used in the analysis.

\begin{tabular}{|c|c|c|}
\hline Variable & Range & Notes \\
\hline \multicolumn{3}{|c|}{$\begin{array}{l}\text { Demographic individual characteristics } \\
\text { Sex: males } \\
\text { Ethnicity: ethnic } \\
\text { minority }\end{array}$} \\
\hline \multicolumn{3}{|l|}{ Cognitive capacities } \\
\hline Non-verbal intelligence & $0-1$ & $\begin{array}{l}\text { Consists of subtests for verbal-linguistic-, mathematical- } \\
\text { and visual-spatial intelligence (van Dijk and Tellegen } \\
\text { 1994). The construct has a validity of } 0.84\end{array}$ \\
\hline School performance & $0-1$ & $\begin{array}{l}\text { Consists of three subtests: Dutch language, mathematics } \\
\text { and information processing) }\end{array}$ \\
\hline School recommendation & $5-9$ & $\begin{array}{l}\text { The recommended track, as given by the teacher in the } \\
\text { final grade of primary education. Scale based on Bosker, } \\
\text { Hofman, and van der Velden (1985) }\end{array}$ \\
\hline \multicolumn{3}{|l|}{ Participation and identification } \\
\hline School motivation & $0-1$ & $\begin{array}{l}\text { Was measured using the following two statements } \\
\text { presented to the students: 'I like to do my homework } \\
\text { well, even if I find it difficult' and 'I don't try to do my } \\
\text { best at school' (reversed) }\end{array}$ \\
\hline School perception & $0-1$ & $\begin{array}{l}\text { Based on a scale with } 11 \text { items on how students perceived } \\
\text { the school ('I like going to school'), their teachers ('My } \\
\text { teachers are always fair') etcetera. It measures the degree } \\
\text { to which a student likes school, and is used as a proxy for } \\
\text { identification with school }\end{array}$ \\
\hline
\end{tabular}

\section{Economic capital}

Social class

Based on the occupation of the breadwinner in the household

\section{Human capital \\ Parental education}

\section{Cultural capital}

Cultural participation

Parents reading books

Social capital

Parental support

Family type: single

parent

Number of children in the family
6-19 Scale based on Bosker, Hofman, and van der Velden (1985)

0-1 Extent to which the parents visited museums, concerts and the theatre

$0-1 \quad$ Number of books read by the parents per month

0-1 Prevalence of parents having discussions about school, having discussions about school performance and giving compliments about school performance Living with a single parent at age 12

Number of siblings at age 12 
Table 1 (Continued)

\begin{tabular}{|c|c|c|}
\hline Variable & Range & Notes \\
\hline \multicolumn{3}{|l|}{ School level } \\
\hline$\%$ of ethnic minorities & & $\begin{array}{l}\text { This proportion is measured as the deviation from the } \\
\text { population mean }\end{array}$ \\
\hline Municipality & & Based on number of addresses per $\mathrm{km}^{2}$ \\
\hline School heterogeneity & & $\begin{array}{l}\text { Does the school provide only the lowest track, or does it } \\
\text { also provide one or both tracks in upper secondary } \\
\text { education? }\end{array}$ \\
\hline
\end{tabular}

where $U_{j}^{(s)}$ is a school-level random effect, assumed to be normally distributed with mean 0 and variance $\sigma_{u}^{2(s)}$.

\section{Empirical results}

Since the main aim of the contribution is to analyse characteristics that influence early school-leaving, we compare each of the three types of early school-leavers to those who did attain a full upper secondary education qualification (see Table 2). However, the table also shows whether effects differ significantly between adjacent groups.

Our analyses show an elevated risk for boys to leave school early. Boys are almost twice as likely to leave school with a low or no qualification. Also, boys are about 2.5 times more likely to continue in an apprenticeship programme. This large effect is mainly a result of the fact that many of these programmes include engineering and technology and are predominately male-oriented. For ethnicity, we find a negative effect, but only when considering students who left after attaining a diploma in lower secondary education. This is quite surprising, as most studies find a higher risk for students from ethnic minorities to leave school early (Marks and Fleming 1999; de Wit and Dekkers 1997; Rumberger 1995). However, they usually do not take into account other characteristics of the students, the family and the school simultaneously as we do in this model.

With respect to cognitive capacities, high school performance, recommended track, positive motivation and positive school perception, all these factors significantly decrease the risk of leaving school early. The only exception is our measurement of intelligence. Students who scored lower on our test for non-verbal intelligence do not have a higher risk of leaving school early. Note that given the interaction term with gender, the estimates in the table present the effects for girls. The interaction effects of gender by cognitive capacities also show significant differences between boys and girls. School performance and motivation affect boys more than girls with respect to their risk of leaving school early. Our theory that effects are strongest for dropouts compared to those with low qualification does not hold for all measures of cognitive ability. We found stronger effects for both performance and motivation, but weaker effects for recommendation. Those who continue education in an apprenticeship programme are shown to be quite a distinctive group with respect to cognitive ability. Although they show significantly lower levels of school performance than the reference group, they are quite similar to 
Table 2. Individual and school-level influences on early school-leaving from lower secondary education ${ }^{2}$ : logit effects (odds ratios in brackets).

Part-time

Lower secondary apprenticeship

No diploma at all education only programme

\begin{tabular}{|c|c|c|c|c|c|c|}
\hline Intercept & $-1.214^{* *}$ & $(0.297)$ & -0.092 & $(0.913)$ & $-1.529 * *$ & $(0.217)$ \\
\hline \multicolumn{7}{|c|}{ Individual level characteristics } \\
\hline \multicolumn{7}{|l|}{ Sex } \\
\hline $\begin{array}{l}\text { Male } \\
\text { Female (ref). }\end{array}$ & $0.612 * *$ & $(1.845)$ & $0.588^{* *}$ & $(1.800)$ & $0.896 * *$ & $(2.449)$ \\
\hline \multicolumn{7}{|l|}{ Ethnicity } \\
\hline Native (ref). & & & & & & \\
\hline Foreign & 0.037 & (1.037) & $-0.184^{*}$ & $(0.832)$ & 0.031 & (1.031) \\
\hline Intelligence & -0.198 & $(0.820)$ & -0.021 & $(0.979)$ & 0.185 & (1.203) \\
\hline School performance & $-2.176^{* *}$ & $(0.113)$ & $-1.221 * *$ & $(0.295)$ & $-1.773 * *$ & $(0.170)$ \\
\hline School recommendation & $-0.331 * *$ & $(0.718)$ & $-0.642 * *$ & $(0.527)$ & -0.077 & $(0.927)$ \\
\hline School motivation & $-1.126^{* *}$ & $(0.324)$ & $-0.459 * *$ & $(0.632)$ & $-0.468 *$ & $(0.626)$ \\
\hline School perception & $-0.432^{*}$ & $(0.649)$ & $-0.466 * *$ & $(0.628)$ & -0.355 & $(0.701)$ \\
\hline \multicolumn{7}{|l|}{ Social class } \\
\hline Manual laborers & $-0.713^{* *}$ & $(0.490)$ & $-0.212 * *$ & $(0.809)$ & $-0.290 * *$ & $(0.748)$ \\
\hline $\begin{array}{l}\text { Self-employed, no } \\
\text { employees }\end{array}$ & $-1.110^{* *}$ & $(0.330)$ & $-0.648^{* *}$ & $(0.523)$ & $-0.764^{* *}$ & $(0.466)$ \\
\hline $\begin{array}{l}\text { Self-employed, with } \\
\text { employees }\end{array}$ & $-0.833 * *$ & $(0.435)$ & $-0.371 * *$ & $(0.690)$ & $-0.800^{* *}$ & $(0.449)$ \\
\hline $\begin{array}{l}\text { Skilled blue-collar } \\
\text { workers }\end{array}$ & $-0.709 * *$ & $(0.492)$ & $-0.281^{* *}$ & $(0.755)$ & -0.237 & $(0.789)$ \\
\hline Office workers & $-0.784 * *$ & $(0.457)$ & $-0.408 * *$ & $(0.665)$ & $-0.432 * *$ & $(0.649)$ \\
\hline Professionals & -0.7 & $(0.475)$ & $-0.649 * *$ & $(0.523)$ & $-0.331^{*}$ & $(0.718)$ \\
\hline \multicolumn{7}{|l|}{ Unemployed (ref). } \\
\hline Parental education & $-0.0713^{* *}$ & $(0.931)$ & $-0.061 * *$ & $(0.941)$ & $-0.037 * *$ & $(0.964)$ \\
\hline Cultural participation & $-0.406^{* *}$ & $(0.667)$ & $-0.343^{* *}$ & $(0.710)$ & 0.058 & $(1.060)$ \\
\hline Reading books & 0.139 & $(1.149)$ & -0.035 & $(0.966)$ & 0.054 & $(1.056)$ \\
\hline Parental support & $-0.656^{* *}$ & $(0.519)$ & $-0.447 * *$ & $(0.639)$ & $-0.375^{* *}$ & $(0.687)$ \\
\hline \multicolumn{7}{|l|}{ Family type } \\
\hline Single parent & $0.263 * *$ & $(1.300)$ & $0.210 *$ & (1.234) & $-0.344^{*}$ & $(0.70$ \\
\hline
\end{tabular}

Two parents (ref).

Number of children in

the family

One child

Two or three children (ref.)

Four children

$0.633^{* *} \quad(1.883) \quad 0.387^{* *} \quad(1.472) \quad 0.133 \quad(1.142)$

School level characteristics

$\%$ of foreign students

Municipality

Very high

$\begin{array}{llllll}\mathbf{0 . 3 1 7 * *} & (1.373) & 0.131 & (1.140) & -0.168 & (0.846)\end{array}$

High

$\begin{array}{lrrrrr}0.013 * & (1.013) & 0.008 & (1.008) & 0.003 & (1.003) \\ 0.162 & (1.176) & -0.201 & (0.818) & -0.055 & (0.946) \\ 0.381 * & (1.464) & 0.152 & (1.164) & 0.295 & (1.343)\end{array}$


Table 2 (Continued)

\begin{tabular}{|c|c|c|c|c|c|c|}
\hline Moderately high (ref.) & \multicolumn{2}{|c|}{ No diploma at all } & \multicolumn{2}{|c|}{$\begin{array}{l}\text { Lower secondary } \\
\text { education only }\end{array}$} & \multicolumn{2}{|c|}{$\begin{array}{l}\text { Part-time } \\
\text { apprenticeship } \\
\text { programme }\end{array}$} \\
\hline $\begin{array}{l}\text { Low } \\
\text { Very low }\end{array}$ & $\begin{array}{l}-0.358^{*} \\
-0.347\end{array}$ & $\begin{array}{l}(0.699) \\
(0.706)\end{array}$ & $\begin{array}{l}-\mathbf{0 . 3 4 4} * * \\
-0.293\end{array}$ & $\begin{array}{l}(0.709) \\
(0.746)\end{array}$ & $\begin{array}{l}-0.103 \\
-0.251\end{array}$ & $\begin{array}{l}(0.902) \\
(0.778)\end{array}$ \\
\hline $\begin{array}{l}\text { School heterogeneity } \\
\text { Includes no higher } \\
\text { education than VMBO } \\
\text { (ref.) }\end{array}$ & & & & & & \\
\hline $\begin{array}{l}\text { Includes higher levels of } \\
\text { education }\end{array}$ & $-0.303^{*}$ & $(0.739)$ & $-0.232 *$ & (0.793) & -0.120 & $(0.887)$ \\
\hline Sex $*$ intelligence & -0.205 & $(0.814)$ & 0.130 & $(1.139)$ & -0.464 & $(0.629)$ \\
\hline Sex $*$ school performance & $-1.036^{* *}$ & $(0.355)$ & $-1.082^{* *}$ & $(0.339)$ & -0.251 & $(0.778)$ \\
\hline $\begin{array}{l}\text { Sex } * \text { school } \\
\text { recommendation }\end{array}$ & -0.079 & $(0.924)$ & 0.117 & $(1.124)$ & $-0.393 * *$ & $(0.675)$ \\
\hline Sex $*$ school motivation & $-0.750 * *$ & $(0.472)$ & $-0.454 * *$ & $(0.635)$ & -0.438 & $(0.645)$ \\
\hline Sex $*$ school perception & 0.221 & $(1.247)$ & 0.178 & $(1.195)$ & 0.476 & $(1.609)$ \\
\hline $\begin{array}{l}2 \text { log likelihood } \\
\text { model } 1 \\
\text { model } 2 \\
\text { model } 3\end{array}$ & $\begin{array}{l}18,128.0 \\
15,875.9 \\
15,471.3\end{array}$ & & & & & \\
\hline
\end{tabular}

Notes: ${ }^{* *}=p<0.01 ; *=p<0.05$ with reference category $=$ left full-time education with a full upper secondary qualification; bold $=p<0.01$; italic $=p<0.05$ with reference category = adjacent group; ref. $=$ reference category.

the other groups. However, they did not receive a significantly lower school recommendation, and they do not perceive school differently than the reference group. And although they show a significantly negative effect for motivation, this is only significant at the 0.05 level.

In general, students from low social classes (i.e. the reference group, non-employed parents) are more at risk of dropping out of school than all other social groups. For students with self-employed parents without employees the risk of dropping out seems to be the smallest. This could be caused by the fact that these students want to take over their parents' business in the future, giving them a clear goal in life. Effects for social class are significantly stronger when considering the risk of leaving school without a diploma ('dropouts') compared to those who leave school after attaining a diploma in lower secondary education ('low-qualified'). Parental education also shows a significant relationship to the risk of dropping out. For every additional year of parental education, the risk of dropping out of school decreases by approximately $7 \%$, although the effect is somewhat smaller for the apprenticeship group.

Cultural participation is negatively linked to the relative risk of dropping out of school or acquiring a low level diploma: having parents who frequently visit museums, concerts and the theatre decreases early school leaving for these two categories, but we find no difference for the group who moved into apprenticeship programmes. Parental reading behaviour showed no significant effect on dropping out. 
The amount of available social capital is important in explaining dropout behaviour. Pupils with very supportive parents are up to $50 \%$ less likely to drop out of school compared to pupils with totally unsupportive parents. At the same time, the family composition and the number of children in a family are also of importance. Children from single-parent families and children in families with four or more children are more at risk of dropping out. However, growing up as an only child also significantly increases the risk of dropping out. This contradicts the assumption that having fewer children increases the transmission of social capital, therefore decreasing the risk of early school-leaving. It may be the case that parents with only one child have more opportunities to continue to work full-time, therefore effectively decreasing the available time per child compared to two-children families. Unfortunately, we were unable to test this hypothesis with our data. The results are different for the group of apprentices. Growing up with a single parent correlates negatively with being in apprenticeship training, while there is no effect of number of siblings.

Relatively large numbers of students from ethnic minorities in a school increase the risk of dropping out, after controlling for the individual effect of being a minority student. Students at an entirely 'black' school are more likely to drop out than those in an entirely 'white' school. In general, a 10\% decrease in the share of students from ethnic minorities in a school results in a $13 \%$ decrease of the dropout risk. Degree of urbanisation of the region in which the school is located only partly correlates with the dropout risk. Students in extremely urban regions are about 1.5 times more at risk of dropping out than students in moderately urban regions. However, dropout risks in regions with a very low and a very high degree of urbanisation do not differ significantly from the risks in moderately urban regions, although this may well be caused by a relatively small number of observations of schools in non-urban regions. Students in lower secondary education attending a school that also provides higher tracks of secondary education are less at risk of dropping out of school or attaining only a low level diploma. So instead of being deterred by being in a more academic environment, students in lower levels of education appear to be encouraged to stay in school as a result of the more academic climate. ${ }^{9}$

\section{Conclusion and discussion}

In this contribution we used an elaborate multilevel model, consisting of individual and family-based characteristics on the first level and school-level factors on the second level, to explain early school-leaving. Most of our hypotheses on factors explaining early school-leaving were confirmed in this study, supporting findings in previous studies on early school-leaving. One important mechanism driving early school-leaving is related to individual abilities and preferences. The student's cognitive abilities and school performance affect the cost of further investment in schooling while the student's motivation will affect the willingness to make such investments. The family resources constitute a second major mechanism. We found clear evidence that the different forms of family capital (economic, human, social and cultural) affect the chances of early school-leaving. While a part of these effects can be interpreted as affecting the costs of investing in education (more resources lower the costs), another part must be interpreted as affecting the relative benefits of investment in education (the returns to education are perceived to be higher for 
students from higher social classes). Finally we also found evidence that school composition factors have an effect on early school-leaving. Although we have taken up only a limited number of school characteristics in our analysis, the results clearly show that schools differ systematically in early school-leaving: schools with high proportions of ethnic minorities show higher dropout rates, while schools that offer higher tracks show lower dropout rates in the low track than schools that only offer the low track. However in future research the influence of the school should be further elaborated on, by adding variables on school climate and school ethos in order to better understand why some schools produce more successful students than others.

This study has advanced the knowledge on who leaves school early and why in at least three important ways.

First, we used an integrated model composed of individual characteristics such as cognitive abilities, family resources (economic, human, cultural and social capital) and school-level variables. By using such an elaborate model we were able to identify better what characteristics explain early school-leaving. An important finding was the stronger effects of cognitive abilities and school motivation on early schoolleaving for boys compared to girls. ${ }^{10}$ The results also underline the importance of family resources, especially in terms of cultural and social capital. A surprising result compared to previous research is the fact that this study found no significant effects for the risk of dropping out of school for students from ethnic minorities when controlling for parental resources like social class and parental education. In fact, when considering the risk of leaving school after graduating from lower secondary education, ethnic minority students are less likely to leave school altogether. One explanation could be that these students are more motivated than native students. Goldsmith (2004) showed that black and Latino students have high occupational expectations, educational aspirations, and concrete attitudes compared to white students, which may serve as a protective factor against early school-leaving. Another study, by Johnson, Crosnou, and Elder (2001), showed that African American adolescents are more actively engaged in classroom and school activities. Thus these students may compensate for the fact that they relatively more often stem from lower social backgrounds by higher levels of motivation and school perception.

A second advancement on previous studies is the differentiation between groups of early school-leavers. Most studies divide early school-leavers into two groups, based on whether they attained a diploma or not. In this study we distinguished four groups of school-leavers, separating 'real' dropouts and early school-leavers who left school after attaining a diploma in lower secondary education from those who continued education either part-time or full-time. In this distinction dropouts can be regarded as the lowest end of a scale of school success ranging from dropout, via leaving education after attaining a diploma in lower secondary education, moving on to an apprenticeship track, to obtaining a full upper secondary qualification. The results show that the effects of all characteristics are always stronger for the dropout group than for the other two groups, suggesting that the underlying dimension is a continuum rather than a distinction between two or three totally different groups.

Finally, we used longitudinal data on a cohort of pupils in the first year of secondary education with a multitude of individual, family and school characteristics that were measured when students were still in the first year. This makes the direction of causality in our findings more plausible. As education is compulsory until the age 
of 16 , we can assume that the data relating to the explanatory factors were measured at least three years before the event of early school-leaving. This makes our findings especially valuable, as it means that we can start combating early school-leaving at an early stage, focusing on students who lack motivation and a positive school perception, students with poor cognitive abilities and students in underprivileged families.

Although this paper focuses on processes underlying early school-leaving in the Netherlands, many of the issues examined in the paper and the findings will apply to other educational contexts within Western society as well. This especially holds true for the gender, social background, motivational and cultural capital effects. Moreover there are two important lessons to be learned from the Dutch context.

One is the importance of a system of apprenticeship or some equivalent like the technical education provided by the vocational and community schools in Ireland. In the Dutch context the apprenticeship system seems to be an important safety net for - mainly male - students who otherwise would have dropped out. Boys have a much higher risk of dropping out than girls and the provision of such a safety net is an important means to combat early school-leaving.

Another important lesson to be taken for other countries is to not solely focus on those who leave school without any diploma, but also set out policies for those that leave school immediately after the school leaving age was reached, having attained very little qualification. Not only do they suffer the disadvantage of being low educated, but they more often also come from disadvantaged backgrounds as was shown in our analyses.

\section{Notes}

1. In $2000,15.5 \%$ of all Dutch 18 -to-24-year-olds were considered early school-leavers; by 2006 this rate had decreased to $12.9 \%$ (Ministry of Education 2006). This is lower than the average of $25 \%$ in all $25 \mathrm{EU}$ countries, but higher than for example in Finland $(7.9 \%)$ or Sweden (8.6\%). In Ireland, the percentage of early school leavers was $12.3 \%$ in 2006 .

2. Apart from individual and environmental factors, other factors such as the economic climate can also affect early school-leaving, pushing and/or pulling young people from school into the labour market. However we do not discuss these factors in this contribution.

3. Although the separation of some of the factors mentioned is quite artificial in some cases, we used this structure for the sake of clarity.

4. However, this effect of gender is not found in all studies (Barrington and Hendricks 1989).

5. The data collection for VOCL is largely based on registry data of enrolment in subsidised education. Therefore, panel attrition and measurement error are not of major concern.

6. At the school level, analyses were carried out on the number of students in the first year, the size of the municipality, region and denomination. Large schools (over 206 students in year one) were underrepresented in the sample while schools with 56-65 students were slightly overrepresented. The largest municipalities were also underrepresented, as well as the Amsterdam region and the whole of the province of North Holland. This was caused by the relatively large proportion of schools in Amsterdam that refused to participate in the study.

7. At the individual level, analyses were carried out on the representativeness of the sample based on the educational tracks provided in the school, gender, school recommendation, availability of parental data from the parental questionnaire, availability of data on ethnicity, the number of students with special needs, the educational and occupational level of the parents and the participation in school performance tests. These analyses showed that the total number of students in pre-vocational secondary education (VMBO) 
in the sample was consistent with the total population in the school year 1999/2000. Students with missing data on ethnicity, parental occupation and parental education were shown to have lower scores on the school recommendation test and the scale for school perception, although these differences were not significant.

8. As all private education is excluded from the VOCL data collection, students may in fact have attained an upper secondary level qualification while this was not included in our data. There are reliable figures on the number of students in private education in the Netherlands, although van der Meer and van der Ploeg (2008) estimated that there were about 34 private schools in the Netherlands with about 1000 students overall, including primary education. Therefore we do not consider this shortcoming of our data design to cause bias in our results.

9. This finding is very much in line with school effectiveness research showing a multiplier effect where students in schools with a high concentration of lower track or lower performing students experience an additional negative effect across a range of outcomes.

10. These findings are in line with previous results found in Serbia (Baucal, Pavlovic-Babic, and Willms 2006).

\section{Notes on contributors}

Tanja Traag works as a researcher at Statistics Netherlands, at the Statistical Analysis Department of the Division of Social and Spatial Statistics in Heerlen. Her current research interests include the transition from school to work, especially short and long term effects of early school-leaving.

Rolf van der Velden is head of the Division of Education and Occupational Career at the Research Centre for Education and the Labour Market (ROA), Maastricht University. He has published on many studies in the field of education, training and the labour market. His current research interests include international comparisons in the transition from school to work, competence development during education, the long term effects of education on occupational careers, overeducation and skills mismatches and the effect of generic and specific competences on labour market outcomes.

\section{References}

Alexander, K., D. Entwisle, and C.S. Horsey. 1997. From first grade forward: Early foundations of high school dropout. Sociology of Education 70: 87-107.

Alexander, K., D. Entwisle, and N. Kabbani. 2001. The dropout process in life course perspective: Early risk factors at home and school. Teachers College Record 103: 760-822.

Audas, R., and J.D. Willms. 2001. Engagement and dropping out of school: A life course perspective. Working Paper for the Applied Research Branch, Strategic Policy, Human Resources Development.

Barrington, B.L., and B. Hendricks. 1989. Differentiating characteristics of high school graduates, dropouts and nongraduates. Journal of Educational Research 826: 309-19.

Baucal, A., Pavlovic-Babic, D., and J.D. Willms. 2006. Differential selection into secondary schools in Serbia. Prospects 36. no. 4: 539-46.

Becker, G.S. 1964. Human capital: A theoretical and empirical analysis, with special reference to education. Chicago, IL: University of Chicago Press.

Beckers, I., and T. Traag. 2005. Jongeren op de arbeidsmarkt. Sociaal-economische Trends 1: 22-6.

Beekhoven, S. 2004. De rol van participatie en identificatie bij het voortijdig schoolverlaten van jongens. Pedagogische Studiën 81: 104-16.

Bosker, R.J., A. Hofman, and R.K.W. van der Velden. 1985. Een generatie geselecteerd. Deel I: De loopbanen. Groningen: RION.

Boudon, R. 1974. Education, opportunity and social inequality. New York: John Wiley. 
Bourdieu, P., and J.C. Passeron. 1977. Reproduction in education, society and culture. London: Sage.

Breen, R., and J.H. Goldthorpe. 1997. Explaining educational differentials. Towards a formal rational action theory. Rationality and Society 9, no. 3: 275-305.

Cairns, R.B., B.D. Cairns, and H.J. Neckerman. 1989. Early school dropout: Configurations and determinants. Child Development 60: 1437-52.

Coleman, J.S. 1988. Social capital in the creation of human capital. American Journal of Sociology 94: S95-S120.

Dijk, H. van, P.J. Tellegen. 1994. Handleiding GIVO Groninger Intelligentietest voor Voortgezet Onderwijs. Lisse: Swets \& Zeitlnger.

DiMaggio, P. 1982. Cultural capital and school succes: The impact of status culture participation on the grades of US high school students. American Sociological Review 47: 189-201.

Driessen, G., and G. van der Werf. 1992. Het functioneren van het voortgezet onderwijs. Beschrijving steekproef en psychometrische kwaliteit instrumenten. Groningen/Nijmegen: RION/ITS.

Ensminger, M.E., and A.L. Slusarcick. 1992. Paths to high school graduation and dropout: A longitudinal study of a first-grade cohort. Sociology of Education 65: 95-113.

Geerdes, S.I. 2009. School-to-work transitions of second generation migrants in West Germany and the Netherlands (dissertation). Bremen: Jacobs University.

Goldsmith, P.A. 2004. Schools' racial mix, students' optimism, and the black-white and Latino-white achievement gaps. Sociology of Education 77: 121-47.

Goldstein, H. 1995. Multilevel statistical models. London: Edward Arnold.

Graaf, N.D. de, and P.M. de Graaf. 2002. Formal and popular dimensions of cultural capital: Effects on children's educational attainment. The Netherlands' Journal of Social Sciences 382: $167-86$.

Graaf, P.M. de 1986. The impact of financial and cultural resources on educational attainment in the Netherlands. Sociology of Education 59: 237-46.

Heard, H.E. 2004. The life course of family structure and adolescent school achievement: Racial and ethnic differences. Paper presented at the Population Association of America 2004 Meeting, Boston.

Johnson, M.K., R. Crosnoe, and G.H. Elder, Jr. 2001. Students' attachment and academic engagement: The role of race and ethnicity. Sociology of Education 74: 318-40.

Lamb, S. 1994. Dropping out of school in Australia: Recent trends in participation and outcomes. Youth and Society 262: 194-222.

Marie, O., T. Traag, and R.K.W. van der Velden. 2009. Education and youth crime: Exploring the causal relationship. Paper presented at the Transitions in Youth Conference, Dijon, September 2009.

Marks, G.N. 1998. Attitudes to school life: Their influences and their effects on achievement and leaving school. Camberwell: Australian Council for Educational Research.

Marks, G.N., and N. Fleming. 1999. Early school leaving in Australia: Findings from the 1995 year 9 LSAY cohort. Camberwell: Australian Council for Educational Research.

McLanahan, S., and G. Sandefur. 1994. Growing up with a single parent. What hurts, what helps? Cambridge, MA: Harvard University Press.

Meer, M. van der and S.W. van der Ploeg. 2008. Particuliere B3-Scholen 2007-2008. Amsterdam: Regioplan.

Ministry of Education. 2006. Bestel in Beeld 2006. The Hague: Ministry of Education.

National Youth Council of Ireland. 2001. Sumission to the NESF project team on early school leaving. Dublin: National Youth Council of Ireland.

Ní Bhrolcháin, M., R. Chappell, I. Diamond, and C. Jameson. 2000. Parental divorce and outcomes for children: Evidence and interpretation. European Sociological Review 161: $67-91$.

O'Brien, M. 2003. Girls and transition to second-level schooling in Ireland: 'Moving on' and 'moving out'. Gender and Education 153: 249-67.

Organisation for Economic Co-operation and Development (OECD). 2007. Education at a glance. Paris: OECD. 
Rumberger, R.W. 1983. Dropping out of high school: The influence of race, sex and family background. American Educational Research Journal 202: 199-220.

Rumberger, R.W. 1995. Dropping out of middle school: A multilevel analysis of students and schools. American Educational Research Journal 323: 583-625.

Shavit, Y., and H.P. Blossfeld. 1993. Persistent inequality: Changing educational attainment in thirteen countries. London: Westview Press.

Slik, F.W.P. van der, W.J.M. Geert, and K.L.J. de Bot. 2005. Ethnic and socioeconomic class composition and language proficiency: A longitudinal multilevel examination in Dutch elementary schools. European Sociological Review 223: 293-308.

Snijders, T.A.B., and R.J. Bosker. 1999. Multilevel analysis. An introduction to basic and advanced multilevel modeling. London: Sage.

Statistics Netherlands. 1987. Standaard Onderwijs Indeling 1978. The Hague: Statistics Netherlands.

Statistics Netherlands. 1991. Schoolloopbaan en achtergrond van leerlingen: cohort 1989. Deel 1: instroom. The Hague: Statistics Netherlands.

US Department of Education. 2001. Fathers' and others' involvement in their children's schools by family type and resident status. Washington, DC: US Department of Education.

Veendrick, L., L. Tavecchio, and J. Doornenbal. 2004. Jongens als probleem. Pedagogiek 241: $12-22$.

Voelkl, K.E. 1995. School warmth, student participation and achievement. Journal of Experimental Education 632: 127-38.

Werf, G.P.C. van der, M. J. Lubbers, and H. Kuyper. 2002. Het interne rendement van het voortgezet onderwijs. Groningen: GION.

Wit, W. de, and H. Dekkers. 1997. Drop-out of startkwalificatie. Omvang, achtergronden en gevolgen van voortijdig schoolverlaten in de eerste vijf jaren voortgezet onderwijs. Tijdschrift voor Onderwijsresearch 224: 211-27.

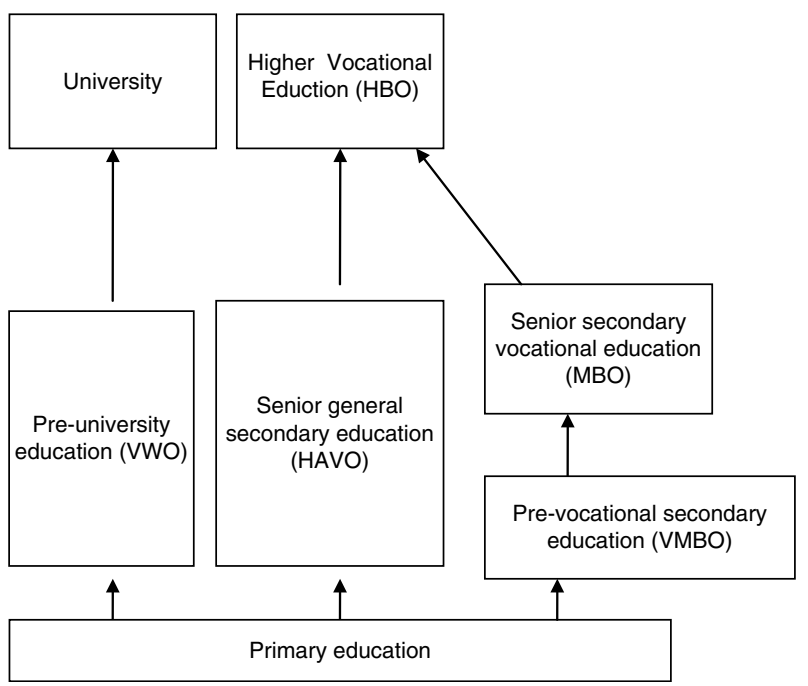

Figure A1. The Dutch educational system. 


\section{Appendix A}

\section{Appendix 1. The Dutch educational system \\ Appendix 2. Measuring background variables, resources and control variables}

Ethnic background is measured by the country of birth of both the respondent and one of his or her parents. Someone is considered to belong to an ethnic minority if either the respondent or his or her parents were born in one of the non-Western countries listed in the Employment of Minorities (Promotion) Act (Wet SAMEN).

The school recommendation is based on the recommendation that students were given by the primary school concerning the type of secondary education for which they were best suited. In the final year of primary education most children complete a test (CITO-toets) which is comparable to the SAT. Based on this test and his/her own observations the primary school teacher will then give advice for the type of secondary education most suitable for the student. This advice was coded on a scale developed by Bosker, Hofman, and van der Velden (1985) expressing the progress towards the top of the educational system. We then subtracted the population mean from the individual school recommendation score.

School performance was based on the total score in three tests (Dutch, mathematics and the ability to process information), which were taken halfway during first grade. Each of the tests consisted of 20 multiple-choice questions. The values of Cronbach's alpha for the three tests were $0.76,0.84$ and 0.77 , respectively. The total score was expressed on a scale from 0 to 1. We then subtracted the population mean from the individual school performance score.

Non-verbal intelligence was measured using two tests. The first sub-test (PSB-3) measured the ability to reason and the second sub-test (PSB-8) the ability to abstract. Both sub-tests contained 40 items. The values of Cronbach's alpha were 0.82 and 0.90 , respectively. The numbers of correct items from both sub-tests were added together and this total sum was transformed to a scale with a minimum value of 0 and a maximum value of 1 . We then subtracted the population mean from the individual non-verbal intelligence score.

School motivation was measured using the following two statements presented to the students: 'I like to do my homework well, even if I find it difficult' and 'I don't try to do my best at school' (reversed). The average of both items was taken. The value of Cronbach's alpha was 0.45 . The total score was transformed to a scale from 0 to 1 . We then subtracted the population mean from the individual school motivation score.

School perception was based on a scale with 11 items on how students perceived the school ('I like going to school'), their teachers ('My teachers are always fair') etcetera. It measures the degree to which a student likes school, and is used as a proxy for identification with school. The value of Cronbach's alpha for this scale was 0.75 . The scores on this scale range from 0 to 1. We then subtracted the population mean from the individual school motivation score.

Two indicators determined the social background of the school-leavers, the educational level of the parents and the social class of the parents. The educational level of the parents was determined according to the Standard Education Classification 1978 (Statistics Netherlands, 1987). The average educational level of both parents was used. The different levels were then converted to the average number of years of education according to the above-mentioned scale by Bosker, Hofman, and van der Velden (1985). The following values were assigned: six years (primary education, ISCED 0-1), 10 years (secondary education, lower level, ISCED 2), 14 years (secondary education, higher level, ISCED 3), 17 years (tertiary education, first phase, ISCED 5 bachelor) and 19 years (tertiary education, second phase, ISCED 5 master or ISCED 6). We then subtracted the population mean from the individual parental educational level.

The social class of the parents was based on information about the type of work and the occupation of the main breadwinner in the family. The following categories were distinguished: (1) not employed; (2) manual laborers; (3) self-employed without employees; (4) self-employed with employees; (5) skilled blue-collar workers; (6) office workers; and (7) professionals.

The cultural resources of the parents were measured according to their degree of cultural participation and their reading behavior. The items used in determining the position on the 
scale for cultural participation concerned the extent to which the parents visited museums, concerts and the theatre. The value of Cronbach's alpha for this scale was 0.88 . The items used in determining the position on the scale for reading behavior concerned the number of books read by the parents per month. The value of Cronbach's alpha for this scale was 0.40 . The scores on both scales were converted to values between 0 and 1 . The amount of parental educational support was based on questions to both parents about having discussions about school, having discussions about school performance and giving compliments about school performance. These items were combined to provide a scale with a minimum value of 0 and a maximum value of 1 . The value of Cronbach's alpha was 0.81 . For these four variables we subtracted the population mean from the individual score.

The type of family was derived from the questionnaire sent out to parents during the first secondary school year. If parents indicated that there was no second parent or caretaker present in the family, the family is considered to be single parent. In the same questionnaire parents were asked how many children were in the family, including the child in the sample.

The school's heterogeneity is divided into two groups: schools where there are only students on the lower secondary education level (i.e. VMBO) and schools that also consist of students from higher levels of secondary education (HAVO and VWO).

The percentage of students from ethnic minorities is computed by dividing the total number of ethnic minorities in the sample in the school by the total number of students in that school. Thus this figure is based on a total of 19,524 students in the initial sample. Then the deviation of the population mean was computed and used in the analysis.

The degree of urbanisation is based on the number of addresses per $\mathrm{km}^{2}$ in the region. If there are 2500 addresses or more, the urbanisation rate is very high. Regions with $1500-2500$ addresses are considered highly urbanised, while regions with 1000-1500 are considered moderately urbanised. Regions with 500-1000 addresses have a low urbanisation rate. Regions with less than 500 addresses are very low urbanised. 